\title{
POST-TRAUMATIC STRESS DISSORDER PADA PENYINTAS ERUPSI GUNUNG KELUD BERDASARKAN IMPACT of EVENT SCALE-REVISED (IES-R) DI DUKUH KALI BLADAK KECAMATAN NGLEGOK KABUPATEN BLITAR (Post-Traumatic Stress Dissorder Of Kelud Mountain's Survivor Based On Impact Of Event Scale-Revised (IES-R) In Kali Bladak Nglegok District Blitar Regency)
}

\author{
Agus Khoirul Anam, Wiwin Martiningsih, Ilus \\ Jurusan Keperawatan, Poltekkes Kemenkes Malang \\ email:_Aguskhoirulanam@gmail.com
}

\begin{abstract}
Post-Traumatic Stress Disorder (PTSD) is an individual response to event or a condition that can appear many symptom such as, re-experiencing, avoidance, hyperarousal. Survivors pschycologicaly often suffering PTSD, if this disorders wasn't detected and ignored without handling by experts, the casualties were often psychologically stressfull pasca trauma. If this condition was undetected and be ignored, it would cause medical and pshycological complication, so that PTSD will disturb social aspect of the patients. The aim of this study was to describe Post-Ttraumatic Stress Disorder in Kelud Mountain's suvivor based on Impact of Event Scale-Revised (IES-R) in Kali Bladak Nglegok district Blitar regency. This research used descriptive design. The number of samples was 42 people who suffered Kelud Mountain's eruption. The result showed that respondents who suffers PTSD was 66,6\% which with less until a lot of symptoms and most of the society experienced Kelud's mountain eruption. The writer suggested that health institutions of Blitar regency could decrease Post Traumatic Stress Disorders symptom from a Kelud's survivor who had many symptoms become no symptoms trough debriefing teraphy in Kali Bladak Village Nglegok District Blitar Regency.
\end{abstract}

Keywords: impact of event scale revised, post-traumatic stress disorder, survivor

\begin{abstract}
Abstrak: Post-Traumatic Stress Disorder (PTSD) adalah respon individu terhadap suatu peristiwa/suatu kondisi yang dapat menimbulkan gejala-gejala, berupa re-experiencing (teringat kembali), avoidance (penghindaran), hyperarousal (peningkatan kewaspadaan berlebihan). Tujuan penelitian adalah menggambarkan Post-Traumatic Stress Disorder Pada Penyintas Erupsi Gunung Kelud Berdasarkan Impact of Event Scale-Revised (IES-R) Di Dukuh Kali Bladak Kecamatan Nglegok Kabupaten Blitar. Metode dalam penelitian ini menggunakan rancangan deskriptif. Populasi dalam penelitian adalah semua penyintas erupsi gunung Kelud di Dukuh Kali Bladak Kecamatan Nglegok Kabupaten Blitar sebanyak 280 orang, dan besar sampel yang diambil adalah 42 orang menggunakan teknik simple random sampling. Pengumpulan data dilakukan dengan memberikan kuesioner IES-R. Waktu pengambilan data dilakukan pada 11 Maret11 April 2015. Hasil penelitian di Dukuh Kali Bladak menunjukkan bahwa responden yang mengalami PTSD sebanyak 66,6\% mulai dari beberapa hingga banyak gejala, dengan sebagian besar masyarakat pernah mengalami peristiwa erupsi Gunung Kelud. Rekomendasi penelitian ini diharapkan dinas kesehatan/ masyarakat dapat menurunkan gejala Post Traumatic Stress Disorders dari seseorang yang menunjukkan banyak gejala menjadi tidak ada gejala pada penyintas erupsi Gunung Kelud melalui terapi debriefing di Dukuh Kali Bladak Kecamatan Nglegok Kabupaten Blitar.
\end{abstract}

Kata Kunci: impact of event scale revised, post-traumatic stress disorder, penyintas 
Indonesia merupakan negara kepulauan terbesar di dunia, memiliki lebih dari 17.480 pulau, terletak diantara dua benua dan dua lautan. Indonesia berada pada pertemuan 3 lempeng dunia, yang berpotensi menimbulkan gempa bumi apabila lempeng-lempeng tersebut bertumbukan. Indonesia juga mempunyai 127 gunung api aktif, 76 diantaranya berbahaya (Kardono, 2010).

Salah satu wilayah rawan bencana di daerah Jawa Timur adalah Kabupaten Blitar. Aktivitas terakhir terjadi pada tahun 2007 diawali dengan peningkatan aktivitas kegempaan dan diakhiri dengan erupsi efusif pada tanggal 3-4 November 2007 berupa kubah lava di tengah danau kawah dengan volume kubah sebesar 16,2 juta $\mathrm{m}^{3}$. Ancaman terbesar bagi warga Kabupaten Blitar adalah lahar, sebab dari 7 jalur pembuangan lahar Gunung Kelud diantara melewati Blitar. Terdapat 16 desa yang terdampak secara langsung dalam radius 5-10 km dari puncak (Sumber: Laporan Tanggap Darurat 2014, BPBD Kabupaten Blitar), yang dihuni oleh lebih dari 115 ribu penduduk. Selain itu warga Blitar juga mewaspadai ancaman debu vulkanik (Nugroho, 2014).

Korban selamat dari bencana disebut penyintas. Adanya trauma pada penyintas erupsi yang tidak segera diatasi tersebut, dapat menimbulkan gangguan yang disebut Post-Traumatic Stress Disorder (PTSD) yang sering terlihat pada peristiwa yang langsung mengancam kehidupan dan peristiwa yang bersifat traumatik (Jose, Juan, dkk, 2005). PostTraumatic Stress Disorder (PTSD) adalah respon individu terhadap suatu peristiwa/suatu kondisi yang dapat menimbulkan gejala-gejala, berupa reexperiencing (teringat kembali), avoidance (penghindaran), hyperarousal (peningkatan kewaspadaan berlebihan) (Schiraldi, 2009), yang lebih sering terjadi pada survivor. Gejala PTSD dapat diikuti dengan gangguan fisik antara lain, tekanan darah tinggi, peningkatan sensitivitas terhadap sakit, masalah pencernaan, sulit tidur, sulit konsentrasi, maupun gangguan mental antara lain, mudah marah, rasa bersalah yang sangat berlebihan North, et al., dalam (Fullerton, et al., 2007).

Cara mendeteksi PTSD dapat menggunakan Impact of Event Scale-Revised (IES-R) yang merupakan salah satu alat ukur baku untuk mendeteksi gangguan PTSD yang disusun berdasarkan kriteria yang ada dalam DSM-IV pada penyintas/survivor bencana pasca erupsi gunung Kelud. Dengan menggunakan alat ukur Impact of Event Scale-Revised
(IES-R) diharapkan mempermudah petugas pelayanan kesehatan untuk melakukan deteksi gangguan PTSD pada penyintas bencana pasca erupsi gunung Kelud guna mengetahui stress pasca trauma yang diderita.

Berdasarkan data jurnal Pratiwi, 2011 persentase masalah mental Post-Traumatic Stress Disorder (PTSD) gunung Merapi setelah 1 tahun paska erupsi merapi sebesar PTSD Berat 28,13\%, PTSD Sedang 53,12\%, PTSD Ringan 18,75\%. Sedangkan menurut depkes.go.id. 2010, kasus insomnia 20\%, PTSD 14,6\% ansietas 5,36\%, depresi $4,64 \%$, mix ansietas depresi sebesar $1,79 \%$, psikosis $1,79 \%$, skizofrenia $0,17 \%$, gangguan penyesuaian $0,53 \%$, lain-lain $50,54 \%$.

Korban bencana seringkali secara psikologis terjangkit gangguan stres pasca trauma/bencana yang pada umumnya dalam dunia kesehatan disebut post traumatic stress disorder (PTSD), yang dapat disembuhkan apabila segera terdeteksi dan mendapatkan penanganan yang tepat. Apabila tidak terdeteksi dan dibiarkan tanpa penanganan, maka dapat mengakibatkan komplikasi medis maupun psikologis yang serius yang bersifat permanen yang akhirnya akan mengganggu kehidupan sosial maupun pekerjaan penderita (Flannery, 1999 dalam Zuhri, 2011).

\section{BAHAN DAN METODE}

Penelitian ini menggunakan deskriptif. Tujuan penelitian ini mendeskripsikan (memaparkan) peristiwa-peristiwa penting yang terjadi pada masa kini. Populasi penelitian ini adalah semua penyintas erupsi gunung Kelud di Dukuh Kali Bladak Kecamatan Nglegok Kabupaten Blitar. Sampel dalam penelitian ini sejumlah 42 responden dengan teknik pengambilan sampel simple random sampling. Kriteria : yaitu penyintas erupsi Gunung Kelud yang berusia dewasa (21 th-55 th). Variabel penelitian ini adalah Post-Traumatic Stress Disorders pada penyintas erupsi gunung Kelud. Post-Traumatic Stress Disorders pada penyintas erupsi gunung Kelud dinilai dengan kuesioner Impact of Event Scale Revised (Weiss \& Marmar, 1997 ) yang berisi gejala-gejala PTSD meliputi: (a) Mengalami kembali (re-experiencing). (b) Penghindaran (avoidance). (c) Peningkatan kewaspadaan yang berlebihan (hyperarousal).

\section{HASIL PENELITIAN}

Pelaksanaan penelitian di dukuh Kali Bladak, dusun Paco, desa Penataran, kecamatan Nglegok, 
kabupaten Blitar yang dilaksanakan pada tanggal 11-20 Maret 2015. Pelaksanaan penelitian dalam bentuk kunjungan rumah (door to door) pada alamat yang telah terpilih secara acak.

Tabel 1. Jenis Kelamin responden

\begin{tabular}{lll}
\hline Jenis Kelamin & N & \% \\
\hline Laki-laki & 18 & 43 \\
Perempuan & 24 & 57 \\
\hline Total & $\mathbf{4 2}$ & $\mathbf{1 0 0}$ \\
\hline
\end{tabular}

Berdasar tabel 1 di atas jenis kelamin responden terbanyak adalah perempuan sebanyak 24 responden $(57 \%)$ dan hanya 18 responden $(43 \%)$ yang berjenis kelamin laki-laki.

Tabel 2. Umur Responden

\begin{tabular}{lcc}
\hline Umur & $\mathbf{N}$ & \% \\
\hline $21-30$ th & 5 & 12 \\
$31-40$ th & 11 & 26 \\
$41-55$ th & 26 & 62 \\
\hline Total & $\mathbf{4 2}$ & $\mathbf{1 0 0}$ \\
\hline
\end{tabular}

Berdasar tabel 2 di atas umur responden terbanyak antara 41-55 tahun. sebanyak 26 responden $(62 \%)$.

Tabel 3. Post-Traumatic Stress Disorders responden di dukuh Kali Bladak pasca 1 tahun bencana erupsi gunung Kelud

\begin{tabular}{clcc}
\hline No. & Kriteria PTSD & N & \% \\
\hline 1 & $\begin{array}{l}\text { Seseorang tidak } \\
\text { memiliki gejala PT SD. }\end{array}$ & 14 & 33,3 \\
2 & $\begin{array}{l}\text { Seseorang memiliki } \\
\text { beberapa gejala PTSD. } \\
\text { Seseorang memiliki } \\
\text { banyak gejala PTSD }\end{array}$ & 71 & 50 \\
\hline & Total & $\mathbf{4 2}$ & $\mathbf{1 0 0 \%}$ \\
\hline
\end{tabular}

Berdasarkan hasil penelitian menunjukkan 14 responden $(33,3 \%)$ tidak memiliki gejala PTSD dan 28 responden $(66,6 \%)$ memiliki gejala PTSD.
Tabel 4. Tabulasi silang jenis kelamin dengan PostTraumatic Stress Disorder responden di dukuh Kali Bladak kecamatan Nglegok kabupaten Blitar, Maret 2015

\begin{tabular}{|c|c|c|c|c|c|c|c|c|}
\hline \multirow[t]{3}{*}{ JK } & \multicolumn{6}{|c|}{$\begin{array}{c}\text { Post-Traumatic Stress } \\
\text { Disorders }\end{array}$} & \multicolumn{2}{|c|}{ Total } \\
\hline & \multicolumn{2}{|c|}{$\begin{array}{c}\text { Tidak } \\
\text { memiliki } \\
\text { gejala } \\
\text { PTSD }\end{array}$} & \multicolumn{2}{|c|}{$\begin{array}{c}\text { Memiliki } \\
\text { beberapa } \\
\text { gejala } \\
\text { PTSD }\end{array}$} & \multicolumn{2}{|c|}{$\begin{array}{c}\text { Memiliki } \\
\text { banyak } \\
\text { gejala } \\
\text { PTSD }\end{array}$} & & \\
\hline & $\mathbf{n}$ & $\%$ & n & $\%$ & n & $\%$ & $\mathbf{N}$ & $\%$ \\
\hline $\begin{array}{l}\text { Laki- } \\
\text { Laki }\end{array}$ & 9 & 21,4 & 7 & 16,7 & 2 & 4,8 & 18 & 42,9 \\
\hline $\begin{array}{l}\text { Perem } \\
\text { puan }\end{array}$ & 5 & 11,9 & 14 & 33.3 & 5 & 11,9 & 24 & 57,1 \\
\hline Total & 14 & 33,3 & 21 & 50,0 & 7 & 16,7 & 42 & 100,0 \\
\hline
\end{tabular}

Berdasarkan hasil tabulasi silang pada tabel 4 diketahui PTSD lebih banyak terjadi pada perempuan. Sebanyak 28 responden $(66,7 \%)$ memiliki gejala PTSD yang meliputi, 9 responden $(21,5 \%)$ terjadi pada laki-laki dan sebanyak 19 responden $(45,2 \%)$ terjadi pada perempuan.

Tabel 5. Tabulasi silang umur dengan Post-Traumatic Stress Disorder responden di dukuh Kali Bladak kecamatan Nglegok kabupaten Blitar, Maret 2015

\begin{tabular}{|c|c|c|c|c|c|c|c|c|}
\hline \multirow[t]{2}{*}{ Umur } & \multicolumn{6}{|c|}{$\begin{array}{c}\text { Post-Traumatic Stress } \\
\text { Disordens }\end{array}$} & \multicolumn{2}{|c|}{ Total } \\
\hline & \multicolumn{2}{|c|}{$\begin{array}{c}\text { Tidak } \\
\text { memili- } \\
\text { ki } \\
\text { gejala } \\
\text { PTSD } \\
\end{array}$} & \multicolumn{2}{|c|}{$\begin{array}{c}\text { Memiliki } \\
\text { beberapa } \\
\text { gejala } \\
\text { PTSD } \\
\end{array}$} & \multicolumn{2}{|c|}{$\begin{array}{c}\text { Memiliki } \\
\text { banyak } \\
\text { gejala } \\
\text { PTSD } \\
\end{array}$} & & \\
\hline Tahun & $\mathrm{n}$ & $\%$ & $\mathrm{n}$ & $\%$ & $\mathrm{n}$ & $\%$ & $\mathrm{~N}$ & $\%$ \\
\hline $21-30$ & 2 & 4,8 & 3 & 7,1 & 0 & ,0 & 5 & 11,9 \\
\hline $31-40$ & 1 & 2,4 & 8 & 19,0 & 2 & 4,8 & 11 & 26,2 \\
\hline $41-55$ & 11 & 26,2 & 10 & 23,8 & 5 & 11,9 & 26 & 61,9 \\
\hline Total & 14 & 33,3 & 21 & 50,0 & 7 & 16,7 & 42 & 100,0 \\
\hline
\end{tabular}

Berdasarkan hasil tabulasi silang pada table 5 diketahui PTSD lebih banyak terjadi pada responden berusia antara 41-55 tahun sebanyak 15 responden $(35,7 \%)$. 
Tabel 6. Tabulasi silang penghasilan per bulan dengan Post-Traumatic Stress Disorder responden di dukuh Kali Bladak kecamatan Nglegok kabupaten Blitar, Maret 2015

\begin{tabular}{|c|c|c|c|c|c|c|c|c|}
\hline \multirow{2}{*}{$\begin{array}{c}\text { Peng } \\
\text { hasilan } \\
\text { per } \\
\text { bulan }\end{array}$} & \multicolumn{6}{|c|}{ Post-Traumatic Stress Disorders } & \multirow{2}{*}{\multicolumn{2}{|c|}{ Total }} \\
\hline & & $\begin{array}{l}\text { dak } \\
\text { niliki } \\
\text { jala } \\
\text { SD } \\
\end{array}$ & $\begin{array}{r}\mathrm{Me} \\
\mathrm{be} \\
\mathrm{g} \\
\mathrm{P}\end{array}$ & $\begin{array}{l}\text { niliki } \\
\text { erapa } \\
\text { jala } \\
\text { SSD }\end{array}$ & & $\begin{array}{l}\text { miliki } \\
\text { nyak } \\
\text { jala } \\
\text { TSD }\end{array}$ & & \\
\hline Juta & $\mathrm{n}$ & $\%$ & $\mathrm{n}$ & $\%$ & $\mathrm{n}$ & $\%$ & $\mathrm{~N}$ & $\%$ \\
\hline$<1$ & 11 & 26,2 & 21 & 50,0 & 7 & 16,7 & 39 & 92,9 \\
\hline $1-2$ & 3 & 7,1 & 0 & .0 & 0 & .0 & 3 & 7,1 \\
\hline Total & 14 & $\mathbf{3 3 , 3}$ & 21 & 50,0 & 7 & 16,7 & 42 & 100,0 \\
\hline
\end{tabular}

Berdasarkan hasil tabulasi silang pada tabel 6 diketahui PTSD lebih banyak terjadi pada responden dengan penghasilan per bulan kurang dari Rp 1.000.000,- sebanyak 28 responden $(66,7 \%)$.

Tabel 7. Tabulasi silang dukungan sosial dengan PostTraumatic Stress Disorder responden di dukuh Kali Bladak kecamatan Nglegok kabupaten Blitar, Maret 2015

\begin{tabular}{|c|c|c|c|c|c|c|c|c|}
\hline \multirow{3}{*}{$\begin{array}{l}\text { Duku } \\
\text { ngan } \\
\text { sosial }\end{array}$} & \multicolumn{6}{|c|}{ Post-Traumatic Stress Disorders } & \multirow{2}{*}{\multicolumn{2}{|c|}{ Total }} \\
\hline & \multicolumn{2}{|c|}{$\begin{array}{c}\text { Tidak } \\
\text { memiliki } \\
\text { gejala } \\
\text { PTSD } \\
\end{array}$} & \multicolumn{2}{|c|}{$\begin{array}{c}\text { Memiliki } \\
\text { beberapa } \\
\text { gejala } \\
\text { PTSD }\end{array}$} & \multicolumn{2}{|c|}{$\begin{array}{c}\text { Memiliki } \\
\text { banyak } \\
\text { gejala } \\
\text { PTSD }\end{array}$} & & \\
\hline & $\mathbf{n}$ & $\%$ & $\mathbf{n}$ & $\%$ & $\mathbf{n}$ & $\%$ & $\mathbf{N}$ & $\%$ \\
\hline $\mathrm{Ya}$ & 14 & 33,3 & 5 & 11,9 & 1 & 2,4 & 20 & 47,6 \\
\hline Tidak & 0 & 0 & 16 & 38,1 & 6 & 14,3 & 22 & 52,4 \\
\hline Total & 14 & $\mathbf{3 3 , 3}$ & 21 & $\mathbf{5 0 , 0}$ & 7 & 16,7 & 42 & 100,0 \\
\hline
\end{tabular}

Berdasarkan hasil tabulasi silang pada tabel 7 diketahui PTSD lebih banyak terjadi pada responden yang tidak memiliki dukungan sosial sebanyak $52,4 \%$ (22 responden).

\section{PEMBAHASAN}

Post-Traumatic Stress Disorder berdasarkan jenis kelamin pada penyintas erupsi gunung Kelud di Dukuh Kali Bladak, Kabupaten Blitar

Berdasarkan hasil penelitian menunjukkan 14 responden $(33,3 \%)$ tidak memiliki gejala PTSD dan 28 responden $(66,6 \%)$ memiliki gejala PTSD.

Perempuan mudah mengalami PTSD. Berdasarkan hasil penelitian menunjukkan bahwa dari 42 (100\%) responden, 24 responden $(57,1 \%)$ berjenis kelamin perempuan, 19 responden $(45,2 \%)$ memiliki gejala PTSD mulai dari beberapa hingga banyak gejala.
Menurut Jose (2005) perempuan memiliki risiko yang lebih besar mengalami distress psikologis, saat terpapar bencana, serta pada dasarnya perempuan rentan ketika terpapar kejadian traumatis, selain itu persepsi atau cara pandang terhadap suatu kejadian antara laki-laki perempuan juga berbeda, perempuan lebih memiliki pandangan secara subjektif terhadap ancaman, bukan dilihat dari sisi objektifnya, hal ini yang membedakan dari laki-laki.

Menurut peneliti responden peneliti sebagian besar adalah kaum perempuan. Perempuan rentan mengalami distress psikologis, salah satunya PTSD. Saat terpapar bencana letusan gunung Kelud, mereka mempersepsikan bahwa bencana erupsi gunung Kelud merupakan suatu kejadian yang menakutkan, selain itu meraka juga memiliki persepsi, serta pikiran terhadap banyak hal misalnya keselamatan anak-anaknya, keluarganya, hal tersebut membuat persepsi perempuan menjadi sempit dan mudah merasa khawatir, persepsi itu yang menyebabkan perempuan mudah mengalami PTSD, dapat dilihat dari data di atas banyak perempuan yang menunjukkan beberapa hingga banyak gejala PTSD.

\section{Post-Traumatic Stress Disorder berdasarkan penghasilan per bulan pada penyintas erupsi gunung Kelud di Dukuh Kali Bladak, Kabupaten Blitar}

Penghasilan yang rendah merupakan faktor risiko terdampak morbiditas psikososial, salah satunya PTSD. Berdasarkan hasil penelitian menunjukkan bahwa dari $42(100 \%)$ responden. 39 responden $(92,9 \%)$ memiliki penghasilan kurang dari Rp $1.000 .000,00$ per bulan, 28 responden $(66,7 \%)$ memiliki gejala PTSD mulai dari beberapa hingga banyak gejala.

Menurut Jose (2005) faktor etnik dan sosioekonomi merupakan faktor risiko yang penting. Faktor sosioekonomi sulit untuk dikaji pada beberapa penelitian, karena dampak komunitas yang relative homogen. Walaupun demikian, sebagian besar penelitian menyatakan bahwa pendidikan yang rendah dan penghasilan yang rendah merupakan faktor risiko terdampak morbiditas psikososial. Individu dapat menganggulangi stress dan kecemasan dengan menggunakan atau mengambil sumber koping dari lingkungan baik dari sosial, intrapersonal dan interpersonal. Sumber koping diantaranya adalah aset ekonomi, kemampuan memecahkan masalah, dukungan sosial budaya yang diyakini (Suliswati, 2005:116). 
Menurut peneliti penghasilan yang rendah merupakan pencetus munculnya beban pikiran, yang selanjutnya dapat mengakibatkan morbiditas psikososial pada seseorang. Dari data di atas banyak masyarakat yang penghasilannya di bawah $\mathrm{Rp}$ 1.000.000 mengalami PTSD. Dengan penghasilan yang rendah mereka kurang memiliki sumber koping yang efektif, sehingga saat mengalami erupsi gunung Kelud, mereka menjadi gampang khawatir dan mengarah pada gangguan PTSD.

Post-Traumatic Stress Disorder berdasarkan usia pada penyintas erupsi gunung Kelud di Dukuh Kali Bladak, Kabupaten Blitar

Berdasarkan hasil penelitian menunjukkan bahwa dari $42(100 \%)$ responden. 26 responden $(61,9 \%)$ berusia $41-55$ tahun. 15 responden $(35,7 \%)$ memiliki gejala PTSD mulai dari beberapa hingga banyak gejala.

Menurut Jose (2005) dampak berdasarkan usia menyebutkan bahwa semakin tua usia seseorang memiliki risiko lebih besar menderita dampak morbiditas atas bencana baik fisik maupun psikis. Norris et all berpendapat bahwa dewasa usia pertengahan lebih mudah terkena terdampak, alasannya seseorang pada usia pertengahan bertanggung jawab atas beban finansial keluarga.

Menurut peneliti seseorang dengan usia pertengahan yaitu 45-60 tahun merupakan usia yang memasuki fase pensiun, namun masih bertanggung jawab terhadap finansial keluarga, hal itu dapat menjadikan beban pikiran yang dapat memicu PTSD. Ditambah lagi adanya bencana erupsi gunung Kelud, yang menumbulkan dapak fisik, seperti kerusakan rumah, kehilangan harta, benda, ternak, menambah beban finansial keluarga. Dari data di atas banyak masyarakat yang berusia 41-55 tahun mengalami PTSD. Stressor inilah yang menyebabkan seseorang dengan usia pertengahan mudah menderita dampak psikologis atas bencana, yaitu PTSD.

Post-Traumatic Stress Disorder berdasarkan dukungan sosial pada penyintas erupsi gunung Kelud di Dukuh Kali Bladak, Kabupaten Blitar

Berdasarkan hasil penelitian menunjukkan bahwa dari $42(100 \%)$ responden. 22 responden $(52,4 \%)$ tidak memiliki dukungan sosial memiliki gejala PTSD mulai dari beberapa hingga banyak gejala.

Menurut Jose (2005) dukungan sosial sering disebutkan sebagai faktor penting yang dapat melindungi individu terhadap paparan bencana. Salah satu kesulitan yang timbul dalam mengkaji pertanyaan mengenai dukungan sosial karena terpisahnya dukungan sosial dari persepsi yang adekuat. Persepsi terhadap dukungan sosial merupakan hal yang kritikal yang ditentukan oleh kepribadian individu. Solomon, et al. (1992), menyatakan bahwa tersedianya dukungan berhubungan dengan outcome baik yang sangat membantu bagi individu, terutama kaum perempuan.

Menurut peneliti dukungan sosial efektif dalam melindungi psikologis individu terhadap paparan bencana. Karakteristik etnik perseorangan pada masyarakat Kali Bladak yang bersifat keras, kurang memiliki kepekaan sosial/empati kepada sesama, menyebabkan tidak adekuatnya dukungan sosial. Berdasarkan data di atas banyak masyarakat dengan dukungan yang tidak adekuat mengalami PTSD. Dukungan sosial seperti perhatian, membantu memecahkan masalah, pemberian pengahargaan merupakan hal penting yang mampu melindungi individu dari dapak psikologis akibat bencana, khususnya PTSD.

\section{Post-Traumatic Stress Disorder berdasarkan tingkat pendidikan pada penyintas erupsi gunung Kelud di Dukuh Kali Bladak, Kabupaten Blitar}

Tingkat pendidikan juga dapat memengaruhi strategi koping individu. Berdasarkan hasil penelitian menunjukkan bahwa $42(100 \%)$ responden. 27 responden $(24,3 \%)$ memiliki tingkat pendidikan sekolah dasar/sederajat. 18 responden $(42,9 \%)$ memiliki gejala PTSD memiliki gejala PTSD mulai dari beberapa hingga banyak gejala.

Menurut Malou, dkk. dalam Davidson (2006: 227) Memiliki intelegensi tinggi tampaknya menjadi faktor protektif, karena hal itu diasosiasikan dengan ketrampilan coping yang lebih baik.

Menurut peneliti seseorang yang memiliki pendidikan rendah sedikit mendapatkan informasi tentang strategi koping/ketahanan jika terdapat bencana erupsi gunung Kelud. Dari data di atas banyak masyarakat dengan pendidikan terakhir sekolah dasar yang mengalami PTSD. Hal ini disebabkan kurang terampilnya menggunakan mekanisme koping, saat terjadi kehilangan dan berduka akibat terjadinya bencana erupsi gunung Kelud. Kebanyakan saat bencana mereka panik, dan khawatir terhadap berbagai hal, hal ini dapat mengarahkan kepada koping yang destruktif. 
Sehingga rentan mengalami PTSD bencana erupsi gunung Kelud.

\section{Post-Traumatic Stress Disorder berdasarkan lama tinggal pada penyintas erupsi gunung Kelud di Dukuh Kali Bladak, Kabupaten Blitar}

Lamanya responden tinggal tidak memengaruhi timbulnya gejala PTSD, Berdasarkan hasil penelitian menunjukkan bahwa dari $42(100 \%)$ responden dan 36 responden $(85,7 \%)$ tinggal di Dukuh Kali Bladak lebih dari 16 tahun, 23 responden $(54,8 \%)$ memiliki gejala PTSD. 5 responden $(11,9 \%)$ memiliki banyak gejala PTSD. 18 responden $(42,9 \%)$ memiliki beberapa gejala PTSD. 13 responden $(31,0 \%)$ tidak memiliki gejala PTSD.

Menurut solomon, et al., dalam jurnal Psychotherapeutic Treatment Of Chronic PTSD, 1993, Banyaknya trauma yang dialami atau dapat disebut juga trauma yang multipel lebih berisiko menjadi PTSD. Prevalensi PTSD juga meningkat sejalan dengan parahnya kejadian traumatik Foy, dkk, 1987. Trauma multiple yang dialami oleh masyarakat lereng gunungapi merupakan kerentanan yang berkembang seiring dengan lama tinggal dan dekatnya masyarakat dari sumber-sumber ancaman lahar dingin, kurangnya akses yang menghubungkan daerah-daerah rawan dengan daerah yang aman.

Lama tinggal tidak berpengaruh pada PTSD, kemungkinan lain PTSD dapat dipicu oleh durasi dan banyaknya paparan peristiwa traumatis masa lalu dan belum adanya penanganan PTSD saat erupsi Gunung Kelud sebelum tahun 2014, sehingga dapat menimbulkan gejala PTSD pada responden di Dukuh Kali Bladak.

Gejala yang sering muncul Post-Traumatic Stress Disorder pada penyintas erupsi gunung Kelud di Dukuh Kali Bladak, Kabupaten Blitar

Berdasarkan hasil penelitian gejala yang sering muncul diantara responden di Dukuh Kali Bladak antara lain terdapat gejala fisik seperti adanya kelelahan fisik, kesulitan untuk tidur serta adanya gangguan tidur, sangat sensitive perasaan dan ingatannya. Gejala emosional yang sering dirasakan adanya perasaan seperti marah, sedih, kaget, bersalah, dan duka mendalam yang bercampur aduk, atau sebaliknya menjadi mati rasa/bebal dalam aktivitas sehari-hari, bersikap waspada berlebihan letusan gunung Kelud yang mungkin akan terjadi. Sedangkan gejala kognitif yang dialami adalah kadang sulit mempercayai informasi, menurunnya penilaian terhadap keadaan dan kemampuan diri, khawatir atau cemas, dan adanya perasaan mudah terganggu oleh pikiran dan ingatan peristiwa erupsi gunung Kelud.

Menurut Davidson, 2006 gejala PTSD yang muncul dapat dikelompokkan menjadi tiga jenis: teringat kembali (re-experience), Penghindaran (avoidance), peningkatan kewaspadaan yang berlebihan (hyperarousal). Re-experiencing gejalanya antara lain, pikiran yang mengganggu tentang kejadian. Mimpi menakutkan yang berulang tentang kejadian. Avoidance gejalanya antara lain, usaha untuk menghindari pikiran, perasaan, dan percakapan yang berhubungan dengan trauma. Peningkatan kewaspadaan yang berlebihan (hyperarou$s a l)$. Kesulitan untuk memulai tidur atau untuk tetap tidur nyenyak. Kewaspadaan berlebihan. Respon terkejut yang berlebihan.

Gejala yang ditunjukkan responden di Dukuh Kali Bladak menunjukkan adanya gejala PostTraumatic Stress Disorder (PTSD) yang disebabkan oleh adanya paparan kejadian traumatis yaitu erupsi Gunung Kelud. Sebagian besar responden di Dukuh Kali Bladak memiliki pengalaman sebagai pengungsi/survivor, banyaknya paparan dan kurangnya penangan PTSD pasca bencana inilah yang memicu responden memiliki gejala PTSD.

Penanganan responden yang memiliki beberapa gejala PTSD, antara lain, terapi debriefing yang bertujuan untuk membantu seseorang, keluarga atau kelompok untuk mengatasi PTSD melalui komunikasi dalam lingkungan yang mendukung dan dipercaya, dapat menggunakan pendekatan kognitif dan behavioral, maupun pendekatan psikoanalisis. Sedangkan penatalaksanaan bagi responden yang memiliki banyak gejala PTSD. pengobatan psikiatrik, yaitu terapi koseling duka dan pengobatan menggunakan obat-obat efektif dilakukan bagi penderita gangguan mental serius dan epilepsi, atau dapat disebut juga sebagai pendekatan biologis, melalui penggunaan berbagai obat-obatan psikoaktif untuk para pasien PTSD, termasuk antidepresan, dan tranquilizer.

\section{SIMPULAN DAN SARAN}

\section{Simpulan}

Responden yang mengalami PTSD di gunung Kelud sebanyak 66,6\% mulai dari beberapa hingga banyak gejala, dengan karakteristik etnik perseorangan pada masyarakat Kali Bladak yang bersifat keras, kurang memiliki kepekaan sosial/empati 
kepada sesama, memiliki pengalaman erupsi Gunung Kelud sebelum tahun 2014. Gejala yang sering muncul antara lain mudah teringat peristiwa erupsi, karena mendengar sedikit suara letusan, sulit tidur, mudah teringat peristiwa erupsi, padahal tidak ingin mengingatnya, mudah gugup dan terkejut, bersikap waspada berlebihan terhadap letusan Gunung Kelud yang mungkin akan terjadi, ingatan tentang erupsi yang terbawa mimpi yang menakutkan.

\section{Saran}

Berikut ini adalah saran-saran yang dapat digunakan untuk memperkuat dan memperbaiki hasil penelitian. Bagi Dinas Kesehatan Kabupaten Blitar diharapkan dengan hasil penelitian ini UPTD Kesehatan Kecamatan Nglegok dan Dinas Kesehatan Kabupaten Blitar memberikan penyuluhan kesehatan dan penanganan Post-Traumatic Stress Disorders masyarakat Kali Bladak melalui terapi debriefing dan medikamentosa. Bagi masyarakat diharapkan masyarakat bisa mencari informasi PTSD dan mengurangi gejala yang muncul melalui tindakan kesehatan. Bagi peneliti selanjutnya diharapkan bagi peneliti selanjutnya dapat meneliti tentang faktor-faktor yang menyebabkan PostTraumatic Stress Disorders dan cara-cara penurunan Post Traumatic Stress Disorders dari seseorang yang menunjukkan banyak gejala menjadi tidak ada gejala.

\section{DAFTAR RUJUKAN}

Administrator BNPB. 2012. Letusan Gunung Berapi. Jakarta. Badan Nasional Penanggulangan Bencana.

Arikunto, S. 2006. Prosedur Penelitian Suatu Pendekatan Praktik. Jakarta: Rineka Cipta.

Bakornas PB. 2007. Pengenalan Karakteristik Bencana dan Upaya Mitigasinya di Indonesia. Jakarta. Direktorat Mitigasi.

Dahlan, M., Sopiyudin. 2011. Statistik untuk Kedokteran dan Kesehatan. Jakarta: Salemba Medika.
Davidson, G.C., Neale, J.M., dan Kring, A.M. Tanpa Tahun. Psikologi Abnormal. Terjemahan oleh Noermalasari Fajar. (2006). Jakarta: RajaGrafindo Persada.

Fullerton, et al. 2007. Textbook of Disaster Psychiatry. United Kingdom: Cambridge University Press.

Hyer, L., dkk. 1993. Psychotherapeutic Treatment of Chronic PTSD. Tahun 1993 Vol 4 No 2: 1-3.

Jose, J., dkk. 2005. Disasters and Mental Health. England: Wiley.

Juneman. 2010. Psikologi Pelayanan Penyintas Bencana. Majalah Merupsy, Tahun 2010 Vol 1 No 2:7-9.

Kardono, P. 2010. Data Bencana Indonesia Tahun 2009. Jakarta: Badan Nasional Penangulangan Bencana.

Keliat, B.A., dkk. 2014. Keperawatan Kesehatan Jiwa Komunitas. Jakarta: EGC.

Mustayah, dkk. 2008. Buku Panduan Karya Tulis Ilmiah Mahasiswa D-III Keperawatan Jurusan Keperawatan Politeknik Kesehatan Dep. Kes. Malang. - : - .

Nevid, J.S., Rathus, S.A., Greene, B. 2003. Psikologi Abnormal. Terjemahan olehTim Fakultas Psikologi Universitas Indonesia. 2005. Jakarta: Erlangga.

Notoatmojo, S. 2010. Metodologi Penelitian Kesehatan. Jakarta: Rineka Cipta.

Nursalam. 2013. Metodologi Penelitian Ilmu Keperawatan. Jakarta: Salemba Medika.

Nugroho, S.P. 2014. Gema BNPB: Ketangguhan Bangsa Dalam Menghadapi Bencana. Vol.5 No.1: Badan Nasional Penanggulangan Bencana.

Schiraldi, G.R. 2009. The Post Traumatic Stress Disorder Sourcebook: Second Edition. USA: The McGrawHill Companies, Inc. (Ebook).

Setiadi. 2013. Konsep dan Praktik Penulisan Riset Keperawatan. Ed. 2. Yogyakarta: Graha Ilmu.

Suliswati, dkk. 2005. Konsep Dasar Keperawatan Kesehatan Jiwa. Jakarta: EGC.

Thompson, R.A. 2004. Strategies that Work in School and Communities: Crisis Intervention and Crisis Management. New York: Brunner-Routledge.

Zuhri, M. 2011. Post Traumatic Stress Disorder (Gangguan Stress Pasca Trauma Bencana) di Jawa Tengah. Jurnal Litbang Provinsi Jawa Tengah. 